\title{
On the saite epithet wr m ntrt, the great one in Netjerit
}

\section{Opinion}

The epithet of the Late Saite non-royal elite member, Neshor Named Psamtikmenkhib, wr $m$ NTrt "the Great One in Netjerit", is interesting and requires a further comment. The first holder of this epithet was the ruler of Sais, Tefnakht, in the great victory stela of Piye $^{2}$. According to JJ Clère, the vizier Bakenrenef, a contemporary of Psamtik I, held this epithet on his libation basin, probably from his tomb at Saqqara ${ }^{3}$. The Late Saite official Wahibre, from the reign of Amasis, had this epithet on his statue Cairo CG 672 ${ }^{4}$. The owner of shabti Vienna no. 5285, the Thirtieth Dynasty ${ }^{5}$ official Djed Hor also held this epithet as HAtj a wr m NTrt m P dp "the HAtj-a, the great one in Netjerit, and in Pe and Dep" ". This refers to the existence of this epithet in Buto as well. The shabti of Tjanefer, also of this dynasty, has HAtj-a wr m NTrt ${ }^{7}$. Yet another Thirtieth Dynasty ${ }^{8}$ monument, statue Cairo JE 43778 of Nectanebo, from the central Delta not far from Sais, gives jrj-pat HAtj-a wr m NTrt. ${ }^{9}$ In addition to Behbeit (Hebyt), the geographical locality of NTrt is sometimes connected

${ }^{1}$ I dedicate this article to my late teacher of Mesopotamian histoy at the Faculty of Archaeology, Cairo University, Dr. Gaballa Ali Gaballa, Professor of History of Ancient Egypt and Near East.

${ }^{2}$ See NC Grimal (1981) La stèle triomphale de Pi('ankh)y au Musée du Caire: JE 48862 et 47086-47089, Paris 5(1.3), 5(12).

${ }^{3}$ See JJ Clère (1982) Un bassin à libations du vizir Bakenrenef. ASAE 68, 84(4-5).

${ }^{4}$ See L Borchardt (1930) Statuen und Statuetten von Königen und Privatleuten im Museum von Kairo Nr. 1-1294. Vol III, Berlin, 18-20; G Posener (1947) Les Douanes de la Méditerranée dans l'Égypte Saïte", RPLHA 21(5): 124, J Yoyotte (2012) Les principautés du delta au temps de l'anarchie libyenne (2nd édn), Le Caire 155(8), H De (1956) Meulenaere Trois Personnages Saïtes. CdÉ 31(5): 252, R El-Sayed (1975) Documents relatifs à Saïs et ses divinités, Le Caire 6: 73-93, C Favard-Meeks (1991) Le temple de Behbeit el-Hagara : Essai de reconstitution et d'interprétation, Hamburg, pp. 389.

${ }^{5} J J$ Clère (1951) Une statuette du fils aîné du roi Nectanabô", RdE 6: 144 wants to date statue Cairo JE 43778 of Nectanebo to the beginning of the Ptolemaic Period on the ground of the presence of the graphical sign of jmjrA, (Clère reads mr and translates "chef"), which is also used in this Thirtieth Dynasty shabti. For the writing of this military title, see W Wreszinski (1906) Aegyptische Inschriften aus dem KK Hofmuseum in Wien, Leipzig pp. 185.

${ }^{6}$ For this example, see Wreszinski, Aegyptische Inschriften aus dem KK Hofmuseum in Wien, 185, who translates "Grosser Fürst in Buto." De Meulenaere, "Trois Personnages Saïtes" 6: 252, Yoyotte, Les principautés du Delta au temps de l'anarchie libyenne 7: 155, W Helck (1974) Die altägyptischen Gaue, Wiesbaden 181; Favard Meeks Le temple de Behbeit el-Hagara 389-390.

${ }^{7}$ See JL Chappaz (1984) Les figurines funéraires égyptiennes du Musée d'art et d'histoire et de quelques collections privées. Genève 158: 123-124, FavardMeeks, Le temple de Behbeit el-Hagara 390.

${ }^{8}$ This statue should be dated to the Thirtieth Dynasty, see Favard-Meeks, Le temple de Behbeit el-Hagara, 687: 390, who does not support the opinion of Clère, "Une statuette du fils aîné du roi Nectanabô" 144[R] and dates it to the Thirtieth Dynasty.

${ }^{9}$ See G Daressy (1912) Statue de Kom Ebchan ASAE 12: 281-2 who translates it "le prince, gouverneur, grand dans Nutrit"; see also De Meulenaere, "Trois Personnages Saïtes" 7: 252, Yoyotte, Les principautés du Delta au temps de l'anarchie libyenne 6: 155, Favard-Meeks, Le temple de Behbeit el-Hagara 390 , miswrites the word wr.
Volume 2 Issue 3 - 2017

\author{
Hussein Bassir \\ Director of the Antiquities Museum, Bibliotheca Alexandrina, \\ Egypt
}

Correspondence: Hussein Bassir, Director of the Antiquities Museum, Bibliotheca Alexandrina, Egypt, Email husseinbassir200I@yahoo.com

Received: November 16, 2017 | Published: December 13, 2017

\section{with Sebennytos, Sema-Behedet, and Sais ${ }^{10}$.}

This honorific epithet has received different readings and translations. H De Meulenaere reads it wr m NTr.t and mentions many instances, in addition to that of Neshor, in which it occurs ${ }^{11}$. C Favard Meeks ${ }^{12}$ reads and translates wr $\mathrm{m}$ NTrt as a separate title after with the title HAtj-a ${ }^{13}$ as "HAtj-a wr m NTrw ${ }^{14}$ Le comte, grand dans NTrw." G Vittmann ${ }^{15}$ points out that Pabasa and others held the title "HAtj-a wr m WAst." He states that the correct reading should be (HAtj-a + wr) m WAst, and not HAtj-a + (wr m WAst). That means he considers wr as an adjective of HAtj-a, rather than standing in its own right as an adjective functions as a noun, "the great one" 16 .

The title HAtj-a + place name was common in the Late Period ${ }^{17}$. The preposition $\mathrm{m}$ and the genitival article $\mathrm{n}$ were used to connect the adjectival noun wr with its toponym. H De Meulenaere ${ }^{18}$ refers to the existence of the title HAtj-a wr m ${ }^{19}$ and the title HAtj-a $w r n^{20}$. ${ }^{10}$ See Favard-Meeks, Le temple de Behbeit el-Hagara 683: 389. For more see also C Favard-Meeks (2002) Les toponymes Nétjer et leurs liens avec Behbeit el-Hagara et Coptos" Topoi Supplément 3: 29-45.

${ }^{11}$ Meulenaere Trois Personnages Saïtes. 252-253. I have recently discussed this epithet in my book, albeit in much less detail; see H Bassir (2014) Image and Voice in Saite Egypt: Self-Presentations of Neshor Named Psamtikmenkhib and Payeftjauemawyneith, Tucson, p. 58-59.

${ }^{12}$ See Favard-Meeks, Le temple de Behbeit el-Hagara, p. 389.

${ }^{13}$ De Meulenaere, "Trois Personnages Saïtes", 252(4) previously made this point.

${ }^{14}$ Favard Meeks, Le temple de Behbeit el-Hagara $389 \mathrm{ff}$., is not consistent and reads nTrt as NTrw, NTr and NTrj. However, Clère, "Une statuette du fils aîné du roi Nectanabô", 144 [R], translates "Neterou."

${ }^{15} \mathrm{G}$ Vittmann (1977) Neues zu Pabasa, Obermajordomus der Nitokris SAK 5(36): 255.

${ }^{16} \mathrm{The}$ book of the temple distinguishes between HAtj-a wr and HAtj-a jmj-jxt. ${ }^{17}$ See De Meulenaere (1958) Le Vizir Harsiêsis de la 30e Dynastie. MDIAK 16: 233. There are more recent discussions of this title and combination of HAtj-a wr n/m, see O Perdu (2006) Documents relatifs aux gouverneurs du Delta au début de la XXVIe dynastie RdÉ 57: 151-88; I Guermeur (2004) Le groupe familial de Pachéryentaisouy. Caire JE 36576 BIFAO 104: 245-89. ${ }^{18}$ There are more recent discussions of this title and combination of HAtj-a wr $\mathrm{n} / \mathrm{m}$, see Perdu, Documents relatifs aux gouverneurs du Delta au début de la XXVIe dynastie 151-188; Guermeur Le groupe familial de Pachéryentaisouy. Caire JE 36576 pp. 245-89.

${ }^{19}$ See De Meulenaere Le Vizir Harsiêsis de la 30e Dynastie. 7: 233.

${ }^{20}$ See De Meulenaere Le Vizir Harsiêsis de la 30e Dynastie. 6: 233. 
E Graefe ${ }^{21}$ refers to the formation of the title $w r m / n+$ toponym with or without HAtj-a. H Ranke ${ }^{22}$ mentions another form of it associated with NTrt, "HAtj-a $n$ mr-NTrt."

\section{Conclusion}

It is obvious that the formation of Neshor's epithet wr m NTrt is different because it independently stands in its own right, and is not directly attached to his title HAtj-a, because his title xtmtj-bjtj

\footnotetext{
${ }^{21}$ E Graefe III (1978) Stellung, Familie und Herkunft des 'Ankh-Hor", In: M Bietak and E Reiser-Haslauer, Das Grab des 'Ankh-Hor: Obersthofmeister der Gottesgemahlin Nitokris I, mit einem Beitrag von E Graefe und Relief und Fundzeichnungen von H Satzinger, vol I, Wien 47; id. “(1974) Die vermeintliche unterägyptische Herkunft des Ibi, Obermajordomus der Nitokris. SAK 1: 202 A4.

${ }^{22} \mathrm{H}$ Ranke (1907) Statue eines hohen Beamten unter Psammetich I. ZÄS 44: 42-54.
}

separates the $\mathrm{two}^{23}$. The designation of this epithet holder is not exactly known; however, H Kees characterizes it as a Saite honorific specification, while De Meulenaere ${ }^{24}$ states that it neither attaches its holder to the families of Behbeit nor confirms whether he was originating from the Delta.

\section{Acknowledgement \\ None.}

\section{Conflict of Interest}

Author declares that there is no conflict of interest.

${ }^{23}$ De Meulenaere Trois Personnages Saïtes. 4: 252 pointed out that the title wr $\mathrm{m}$ Trt is not attached to the title HAtj-a as in the other examples that he brings up.

${ }^{24}$ See De Meulenaere Trois Personnages Saïtes. pp. 253. 